\title{
Optimization of Titanium Dioxide Nanoparticles in Mesoporous Electron Transport Layer Perovskite Solar Cell
}

\author{
Deborah Augustine $^{\text {a,* }}$, Erlyta Septa Rosa ${ }^{\text {b }}$, Niki Prastomo ${ }^{\text {c }}$, Shobih ${ }^{\text {b }}$ \\ ${ }^{a}$ Department of Physics Energy Engineering \\ Surya University \\ F8 \& F9 Grand Serpong Mall, Jl. MH Thamrin Panuggangan Utara, Pinang \\ Tangerang, Indonesia \\ ${ }^{b}$ Research Center for Electronics and Telecommunication \\ Indonesia Institute of Sciences (P2ET-LIPI) \\ Komplek LIPI Gedung 20 Lt.4, Jl. Sangkuriang Cisitu \\ Bandung, Indonesia \\ ${ }^{c}$ Department of Physics Engineering \\ Universitas Multimedia Nusantara \\ Jl. Scientia Boulevard, Gading Serpong \\ Tangerang, Indonesia
}

\begin{abstract}
Research about mesoporous $\mathrm{TiO}_{2}$ as an electron transport layer in perovskite solar cell has been done to obtain the best fabricated cell's performance. In this research, the concentrations of opaque and transparent $\mathrm{TiO}_{2}$ nanoparticle were varied, in order to optimize the $\mathrm{TiO}_{2}$ mesoporous electron transport layer in FTO/CL-TiO$/ \mathrm{MS}-$ $\mathrm{TiO}_{2} /$ Perovskite/P3HT/Ag perovskite-based solar cell. Morphological, optical, and electrical characteristics of $\mathrm{TiO}_{2}$ layers were investigated using scanning electron microscopy (SEM), four-point probe (FPP), and UV-Vis spectroscopy. The influences of those characteristics in solar cell performance were analyzed by using illumination of sun simulator with a light intensity of $500 \mathrm{~W} / \mathrm{m}^{2}$. The results showed that transparent $\mathrm{TiO}_{2}$ has a higher conductivity and transmittance compared to the opaque $\mathrm{TiO}_{2}$. The concentration of $\mathrm{TiO}_{2}$ solution in 1:17 ratio resulted in higher electrical performance in both the transparent and opaque $\mathrm{TiO}_{2}$ layer. The best perovskite solar cell performance with $\mathrm{PCE}$ of $0.37 \%$ was achieved from the sample using $\mathrm{TiO}_{2}$ transparent layer with a concentration of $1: 7$ ratio.
\end{abstract}

Keywords: mesoporous $\mathrm{TiO}_{2}$, electron transport layer, perovskite solar cell.

\section{INTRODUCTION}

Perovskite solar cell (PSC) is one of the $3^{\text {rd }}$ generation solar cells that has a simpler and low-cost fabrication [1]. Organometal halide, specifically leads methyl ammonium triiodide $\left(\mathrm{CH}_{3} \mathrm{NH}_{3} \mathrm{PbI}_{3}\right)$ has a perovskite structure, which can be used as an active light-absorbing layer because of its direct bandgap, a large absorption coefficient, good electron and hole conductivity, and high charge carrier mobility [2,3].

Typical device architectures of PSC consist of thin layers of transparent conductive oxide (TCO), electrontransporting layer (ETL), perovskite light-absorber layer, hole transport layer (HTL), and a metal electrode [4]. Depending on the sequence of depositing the ETL and HTL, the device structure can be divided into conventional versus inverted architectures. The order and chemical nature of the layers and the metal electrode strongly condition the performance of PSC [5].

The electron-transporting layer plays a crucial part in the PSC because it prevents the carriers from directly

\footnotetext{
* Corresponding Author.

Email: deborahaugustine135@yahoo.co.id

Received: November 13, 2019 ; Revised: November 27, 2019

Accepted: April 21, 2020 ; Published: August 31, 2020

(C) 2020 PPET - LIPI
}

contacting the conductive substrate and thereby shunting the device. Inorganic semiconductors such as titanium dioxide $\left(\mathrm{TiO}_{2}\right)$ and zinc oxide $(\mathrm{ZnO})$ are often used as an electron transport layer in PSC. Organic materials such as PCBM, C60, and their derivatives can also be used with inverted architecture [6]-[8].

Titanium dioxide is the most common material used because it has a suitable fermi level with lead methyl ammonium triiodide or $\mathrm{MAI}\left(\mathrm{CH}_{3} \mathrm{NH}_{3} \mathrm{PbI}_{3}\right)$ perovskite, so that electron could easily be injected into its conductive band [9]. Relatively stable, long electron lifetime and simple fabrication methods are also the factors why $\mathrm{TiO}_{2}$ is selected as an electron transport material [10]. Spin coating (SC) and spray pyrolysis (SP) are two representative solution processes used to form $\mathrm{TiO}_{2} \mathrm{ETL}$, although atomic layer deposition (ALD), thermal oxidation, $\mathrm{TiCl}_{4}$ chemical bath deposition, and screen printing have also been reported in the literature [11]. It is generally acknowledged that the quality of ETL produced is highly sensitive to process parameters, and thus the efficiency and reproducibility can vary substantially. The quality of the ETL can be improved by controlling both layer thickness and morphology. ETL thickness is very influential on the ease of electrons to flow to the anode and the optical properties of cells [12]. Mesoporous 
structure of the ETL surface can lead perovskite to enter the pores and causes a larger surface area of the perovskite layer [13]. Although the properties of the $\mathrm{TiO}_{2}$ layer in solid-state PSCs have been widely investigated, thickness- and morphology-dependent effects of the mesoscopic $\mathrm{TiO}_{2}$ layer are still unclear. Therefore, in this study, these parameters will be investigated to obtain the optimum ETL $\mathrm{TiO}_{2}$ layer in the process of making perovskite solar cells. The $\mathrm{TiO}_{2}$ material used in this research is transparent and opaque $\mathrm{TiO}_{2}$ pastes. The transparent paste contains a uniform of $20 \mathrm{~nm} \mathrm{TiO}_{2}$ particles, while opaque $\mathrm{TiO}_{2}$ paste contains a mixture of $20 \mathrm{~nm}$ and $450 \mathrm{~nm} \mathrm{TiO}_{2}$ particles. In this research, the $\mathrm{TiO}_{2}$ layers were deposited by a spin coating method, and because of the material used is in the form of a paste, it is necessary to dilute the pastes to make it possible to do the spin coating process. The concentration of the $\mathrm{TiO}_{2}$ solution was varied by diluting $\mathrm{TiO}_{2}$ pastes in ethanol, with a mass ratio of $1: 3$, $1: 5,1: 7,1: 9$, and 1:11, respectively.

\section{EXPERIMENTAL SECTION}

\section{A. Materials}

The substrate used in this research is fluorine-doped tin oxide (FTO) glass coated with a sheet resistivity of $\sim 15 \Omega$ /sq (Dyesol, TEC15). $\mathrm{TiO}_{2}$ opaque (18NR-AO) and transparent (18NR-T) pastes were also purchased from Dyesol. $\mathrm{TiCl}_{4}$ synthetic grade was obtained from Merck, while $\mathrm{CH}_{3} \mathrm{NH}_{3} \mathrm{I}$ (MAI), $\mathrm{PbI}_{2}, \mathrm{DMF}$, chlorobenzene, isopropyl alcohol, and silver wire were ordered from Sigma Aldrich as a pure analyzed grade.

\section{B. Procedure}

FTO glass substrates with the size of $2 \mathrm{~cm} \times 1.5 \mathrm{~cm}$ were sonicated in Teepol, deionized (DI) water, and isopropyl alcohol (IPA) for 10 minutes, respectively. After being dried in the air, the substrates were immersed in $40 \mathrm{mM} \mathrm{TiCl} 4$ solution at $70^{\circ} \mathrm{C}$ for 30 minutes, then they were rinsed with Deionized (DI) water and then annealed at $500^{\circ} \mathrm{C}$ for 30 minutes in the furnace to form $\mathrm{TiO}_{2}$ compact layer.

TABLE 1

RESEARCH SAMPLE MAPPING

\begin{tabular}{|c|c|c|c|c|}
\hline No & $\begin{array}{l}\text { Sample } \\
\text { Name }\end{array}$ & Type of $\mathrm{TiO}_{2}$ & $\begin{array}{c}\text { Particle } \\
\text { Size } \\
(\mathbf{n m})\end{array}$ & $\begin{array}{l}\mathrm{TiO}_{2} \text { : Ethanol } \\
\text { Ratio }(\mathbf{w} / \mathbf{w})\end{array}$ \\
\hline 1 & $1: 3 \mathrm{~T}$ & \multirow{5}{*}{$\begin{array}{c}\text { 18NR-T } \\
\text { (Transparent) }\end{array}$} & \multirow{5}{*}{20} & $1: 3$ \\
\hline 2 & $1: 5 \mathrm{~T}$ & & & $1: 5$ \\
\hline 3 & $1: 7 \mathrm{~T}$ & & & $1: 7$ \\
\hline 4 & $1: 9 \mathrm{~T}$ & & & $1: 9$ \\
\hline 5 & $1: 11 \mathrm{~T}$ & & & $1: 11$ \\
\hline 6 & $1: 3 \mathrm{AO}$ & \multirow{5}{*}{$\begin{array}{l}\text { 18NR-AO } \\
\text { (Opaque) }\end{array}$} & \multirow{5}{*}{$20-450$} & $1: 3$ \\
\hline 7 & $1: 5 \mathrm{AO}$ & & & $1: 5$ \\
\hline 8 & 1:7 AO & & & $1: 7$ \\
\hline 9 & $1: 9 \mathrm{AO}$ & & & $1: 9$ \\
\hline 10 & $1: 11 \mathrm{AO}$ & & & $1: 11$ \\
\hline
\end{tabular}

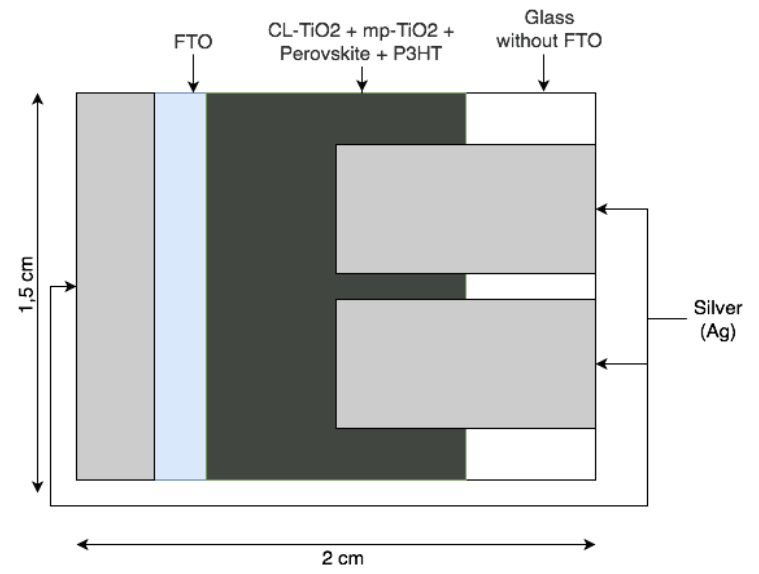

(a)

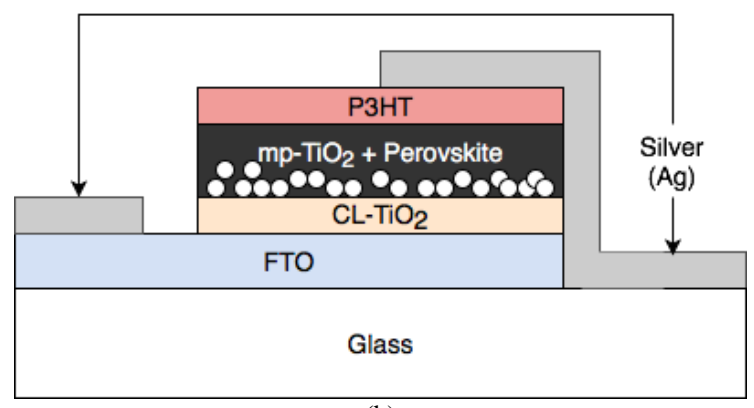

(b)

Figure 1. Device Structure: (a) Top view, (b) Side view.

In this study, we use two types of $\mathrm{TiO}_{2}$ pastes, which are commercially available. The opaque $\mathrm{TiO}_{2}$ paste contains a mixture of $20 \mathrm{~nm}$ and $450 \mathrm{~nm} \mathrm{TiO}_{2}$ nanoparticles; meanwhile, the transparent one contains a uniform of $20 \mathrm{~nm}$ nanoparticles. Both of these pastes have very high viscosity. The spin coating technique used in this study requires materials with low viscosity. Therefore, the two pastes need to be diluted first. The $\mathrm{TiO}_{2}$ pastes were diluted in ethanol as a dispersant. Since the paste has a very high viscosity, it is more convenient to prepare the samples with mass ratio, not volume ratio [14]. The concentration was varied in the mass ratio of $1: 3,1: 5,1: 7,1: 9$, and $1: 11$, respectively. Table 1 shows the name of samples, type of paste, and the ratio between $\mathrm{TiO}_{2}$ and ethanol, which were used.

A $75 \mu$ of the $\mathrm{TiO}_{2}$ solution was spin-coated on the substrates at $5000 \mathrm{rpm}$ for 30 seconds and dried at $70^{\circ} \mathrm{C}$ for 10 minutes in the oven, before annealing the substrates in the furnace at $500{ }^{\circ} \mathrm{C}$ for 30 minutes. $\mathrm{MAPbI}_{3}$ perovskite solution was prepared by mixing MAI and $\mathrm{PbI}_{2}$ in a molar ratio of 1:1 in DMF, resulting in a concentration of $35 \mathrm{wt} \%$. The solution was stirred overnight at $65^{\circ} \mathrm{C}$ in order to dissolve it uniformly. A 75 $\mu l$ perovskite solution was spin-coated at $4500 \mathrm{rpm}$ for 30 seconds. At 4 th second in the spin-coating process, $150 \mu \mathrm{l}$ of chlorobenzene as anti-dispersant was dropped onto the spinning substrate. The perovskite layers were annealed on a hotplate at $95^{\circ} \mathrm{C}$ for 30 minutes.

A solution of $15 \mathrm{mg}$ poly-3hexylthiopene (P3HT) in $1 \mathrm{ml}$ chlorobenzene was prepared as HTL. The solution was stirred for 2 hours and then spin-coated on the surface of the perovskite layer at $3000 \mathrm{rpm}$ for 30 seconds. The substrates were annealed on the hotplate at 
$95^{\circ} \mathrm{C}$ for 10 minutes. Finally, a 70 nm-thick silver electrode was deposited by thermal evaporation onto P3HT layer at a vacuum pressure of $5 \times 10^{-5} \mathrm{mBar}$. The device structure can be seen in Figure 1.

\section{Characterization}

The morphology characteristics of the mesoporous $\mathrm{TiO}_{2}$ layer were observed using a $20 \mathrm{kV}$ scanning electron microscopy (SEM) JEOL JSM IT-300. The layer thickness was also obtained using the scaled crosssection images that had been generated by SEM. Meanwhile, the transmittance spectra of the electron transport layer were obtained with an ultraviolet spectrophotometer (Hewlett Packard 8453 Agilent Technologies). The sheet resistance of the $\mathrm{TiO}_{2}$ layers was measured by a four-point probe using an HP 3468A electrometer. The photovoltaic performance of the fabricated perovskite solar cells was measured by the National Instrument I-V measurement system using sun simulator (Oriel, Newport, USA, AM1.5G) with the intensity of $500 \mathrm{~W} / \mathrm{m}^{2}$.

\section{RESUltS AND DISCUSSION}

The configuration of the device was FTO/CL$\mathrm{TiO}_{2} / \mathrm{MS}-\mathrm{TiO}_{2} /$ Perovskite/P3HT/Ag. Band-alignment of anode, electron transport layer $\left(\mathrm{TiO}_{2}\right)$, light-absorbing layer (perovskite), hole transport layer (P3HT), and the cathode $(\mathrm{Ag})$ is shown in Figure 2. This energy-level diagram could also be used to calculate open-circuit voltage $\left(\mathrm{V}_{\mathrm{oc}}\right)$ in theory, which is the difference between lowest unoccupied molecular orbital (LUMO) energy or conduction band in the electron transport layer and highest occupied molecular orbital (HOMO) or valence band in hole transport layer [15]. LUMO of $\mathrm{TiO}_{2}$ is -4.1 $\mathrm{eV}$; meanwhile, HOMO of $\mathrm{P} 3 \mathrm{HT}$ is $-5.2 \mathrm{eV}$. By definition, the value of $\mathrm{V}_{\mathrm{oc}}$, in theory, is LUMO $\left(\mathrm{TiO}_{2}\right)$ $-\mathrm{HOMO}(\mathrm{P} 3 \mathrm{HT})$, which is $-4.1 \mathrm{eV}-(-5.2 \mathrm{eV})$ or 1.1 $\mathrm{eV}$.

SEM images of the surface morphology of opaque and transparent $\mathrm{TiO}_{2}$ mesoporous layer in different concentrations were shown in Figure 3. It was observed in the figure that random large particles are present between fine particles on the opaque $\mathrm{TiO}_{2}$ layer.

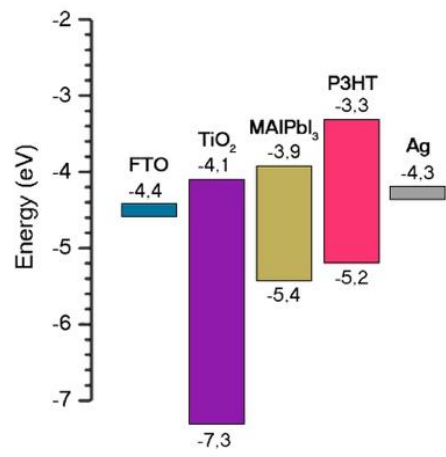

Figure 2. Schematic energy-level diagram for layers in the fabricated perovskite solar cell.
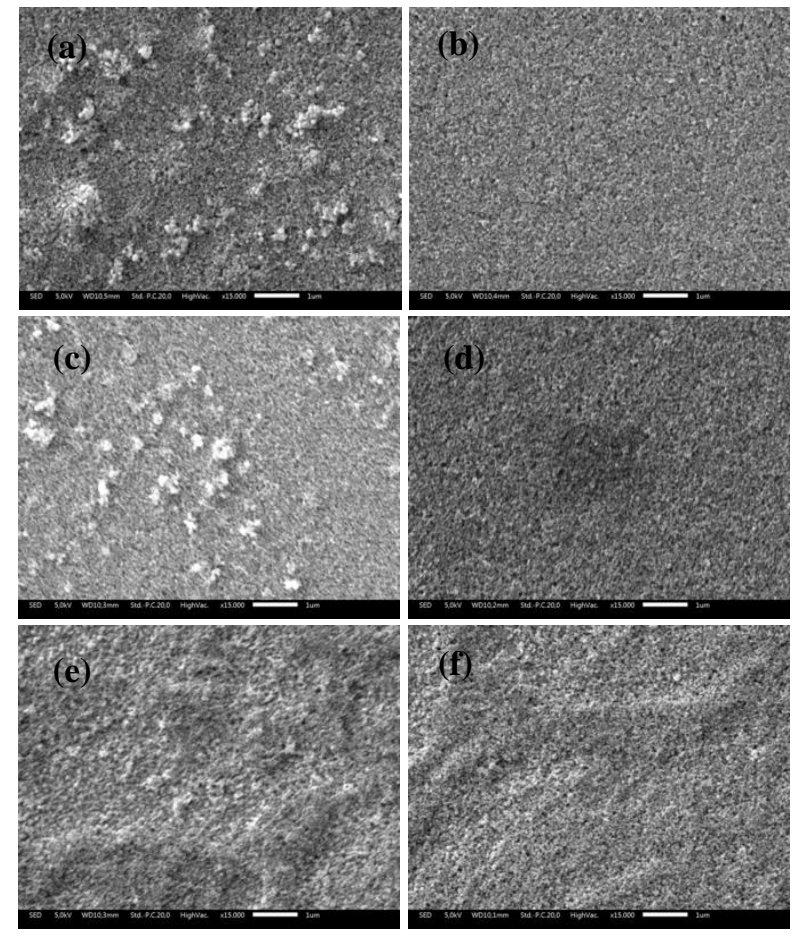

Figure 3. SEM images of $\mathrm{TiO}_{2}$ ETL surface: (a) 1:3 AO, (b) 1:3 T, (c) 1:7 AO, (d) 1:7 T, (e) 1:11 AO, and (f) 1:11 T.

The number of large particles decreases with decreasing concentration of $\mathrm{TiO}_{2}$ paste, so the surface tends to be smoother. Different from the opaque $\mathrm{TiO}_{2}$ layer, in a transparent $\mathrm{TiO}_{2}$ layer, the layer produces a uniform surface with evenly distributed particle size. The surface becomes increasingly uneven with decreasing concentration. It also shows the formation of contours with decreased concentration, both on the opaque and transparent $\mathrm{TiO}_{2}$ layer.

The thickness of the $\mathrm{TiO}_{2}$ layers was measured from the SEM image of the cross-section side of the samples (Figure 4). Figure 5 shows the thickness of the transparent and opaque $\mathrm{TiO}_{2}$ layer under different concentration (ratio). Each samples' thickness was measured in three different points, and by those thickness data, error bars in Figure 5 were calculated. It was observed that increasing $\mathrm{TiO}_{2}$ concentration in the solution would thicken the deposited layer for both opaque and transparent pastes. This observation verifies that $\mathrm{TiO}_{2}$ mesoporous structure's thickness could be adjusted by varying $\mathrm{TiO}_{2}$ concentrations in the solution or by arranging the ratio of $\mathrm{TiO}_{2}$ paste and ethanol. Figure 5 also shows that opaque $\mathrm{TiO}_{2}$ produces a thicker layer than the transparent one. The result from the $\mathrm{TiO}_{2}$ opaque device is thicker than the device with the $\mathrm{TiO}_{2}$ transparent layer because it has some broader particle sizes, either smaller or bigger particles $(20 \mathrm{~nm}$ and 450 $\mathrm{nm}$ ). While the device with the $\mathrm{TiO}_{2}$ transparent layer a uniform particle size around $20 \mathrm{~nm}$. Ito et al. also found that the $\mathrm{TiO}_{2}$ layer would thicken as its particle was increasing in size without changing its solution volume in the deposition process [16]. 


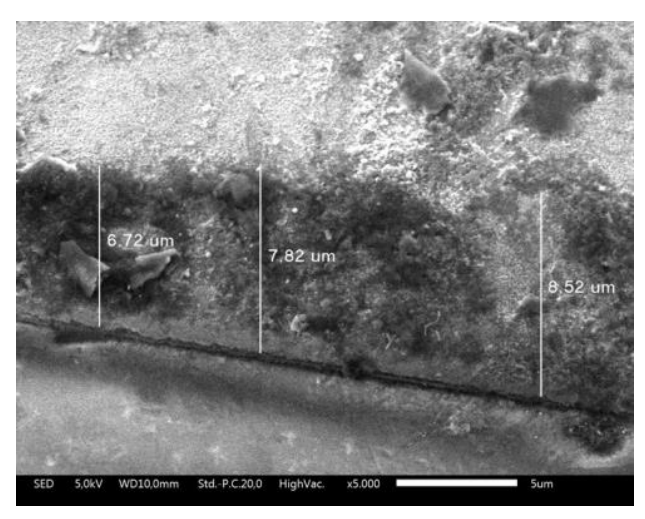

Figure 4. Thickness measurement of the $\mathrm{TiO}_{2}$ layer by SEM image through the cross-section side of the $\mathrm{TiO}_{2}$ layer.

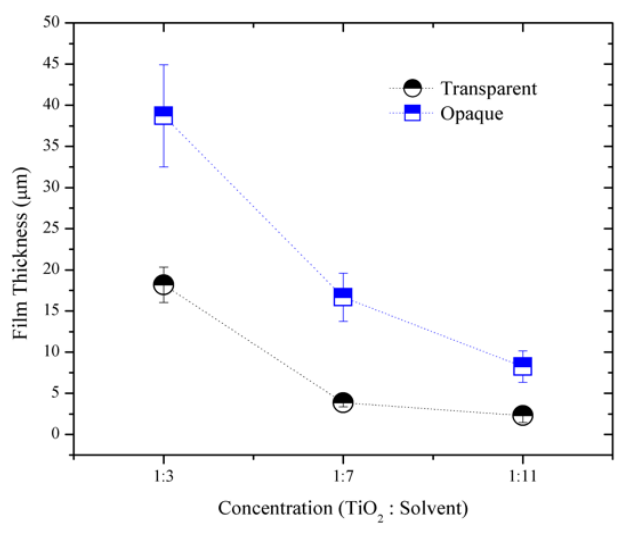

Figure 5. Thickness of $\mathrm{TiO}_{2}$ mesoporous electron transport layer of different type of $\mathrm{TiO}_{2}$ paste under different concentration

The thickness of a $\mathrm{TiO}_{2}$ layer could affect the electron-hole recombination rate in the perovskite solar cell [13]. A thinner electron transport layer would have a shorter electron travel distance and reduce the cell's recombination rate. However, a thinner layer would reduce the deposited perovskite volume on it because of its mesoporous structure that acts as a scaffold for the perovskite layer [14].

An optical characteristic of the $\mathrm{TiO}_{2}$ layer can be seen in Figure 6. As the name suggests, $\mathrm{TiO}_{2}$ opaque produces an opaque layer, and on the other hand, $\mathrm{TiO}_{2}$ transparent produces a transparent layer. Thus, the $\mathrm{TiO}_{2}$ transparent layer was able to transmit light better than the $\mathrm{TiO}_{2}$ opaque layer, as seen in the transmittance curve in Figure 6. Both $\mathrm{TiO}_{2}$ transparent and opaque have a high transmittance in the visible region (400 $800 \mathrm{~nm})$, but in the ultraviolet region $(400 \mathrm{~nm})$ has a low transmittance. These optical properties are due to optical properties of $\mathrm{TiO}_{2}$ nanoparticle itself that is able to absorb ultraviolet because of its wide bandgap of 3.0 $\mathrm{eV}-3.2 \mathrm{eV}[10]$.

From Figure 6(a), we can see that substrate with $\mathrm{TiO}_{2}$ transparent did not have any significant difference between ratios of $\mathrm{TiO}_{2}$ and ethanol. The highest transmittance of $93 \%$ is obtained by sample 1:9 T, while sample 1:7 T has the lowest transmittance value of $75 \%$. In theory, sample 1:11 $\mathrm{T}$ should have the highest transmittance value. However, that position was obtained by sample 1:9 T. This could be caused by the uneven surface contour of sample $1: 11$, as seen in
Figure 3(f). When light meets an object with an uneven surface, it will be scattered. Hence it reduces the transmitted light [14].

On the other hand, samples with $\mathrm{TiO}_{2}$ opaque have a significant difference between each concentration ratio value, as can be seen in Figure 6(b). Mainly in ratio 1:3 and $1: 11$, where the value is $4 \%$ and $74 \%$ respectively in wavelength of $\sim 480 \mathrm{~nm}$. It was shown that the transmittance is decreasing with increasing $\mathrm{TiO}_{2}$ concentration. One of the possible causes is the increase of the layer thickness as $\mathrm{TiO}_{2}$ concentration increases. When the layer thickens, the transparency of a layer will be reduced, and thus, transmittance value becomes less because the light will be absorbed by the addition layer [17].

As seen in Figure $6 a$ and $b$, the control sample has a lower transmittance value than all transparent paste samples and opaque paste with a concentration of 1:9 and 1:11. This result is caused by the difference of $\mathrm{TiO}_{2}$ material used in the deposition process. In the control sample, $\mathrm{TiO}_{2}$ compact layer is deposited by the chemical bath method using $\mathrm{TiCl}_{4}$ as the base material, whereas in other samples, $\mathrm{TiO}_{2}$ is deposited by spincoating using commercially available $\mathrm{TiO}_{2}$ paste that has nano-sized particle and more even particle size distribution.

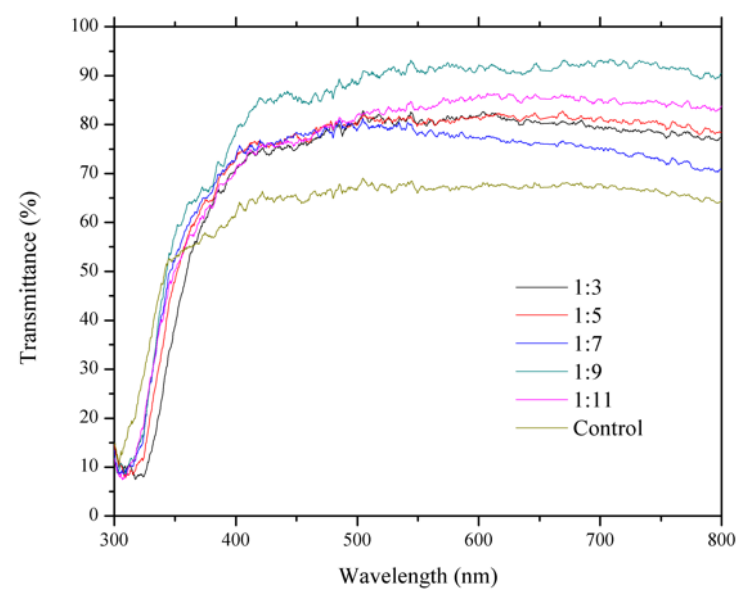

(a)

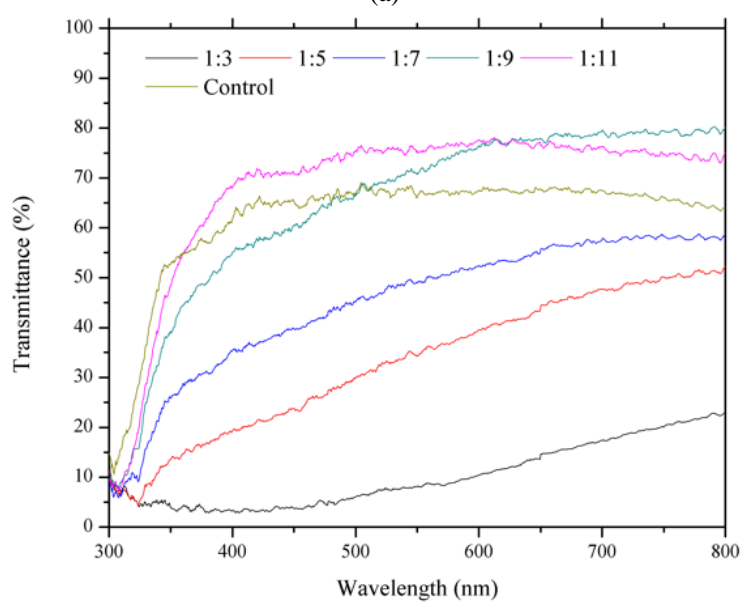

(b)

Figure 6. Ultraviolet-visible transmittance spectra of $\mathrm{TiO}_{2}$ mesoporous electron transport layer with: (a) Transparent and (b) Opaque 


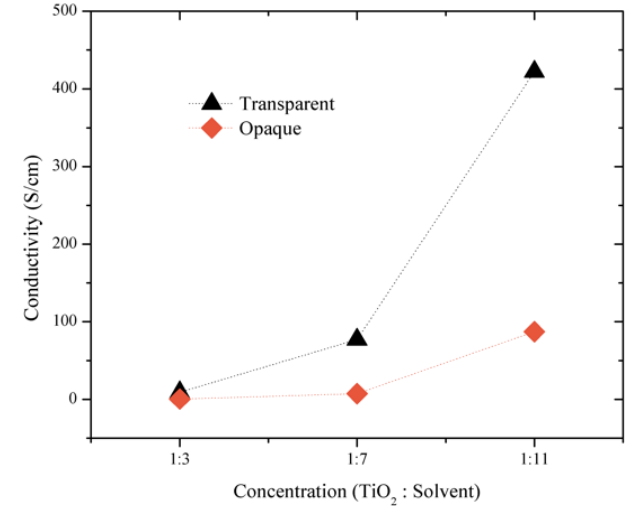

Figure 7. Electrical conductivity of $\mathrm{TiO}_{2}$ mesoporous electron transport layer under different $\mathrm{TiO}_{2}$ concentration

The electrical characteristic of a layer is one of the important factors for deciding whether a material is good for the electron transport layer. Ideally, the electron transport layer should have high conductivity, because it will increase the performance of charge accumulation and transfer process from the perovskite layer to electrode [3]. The electrical conductivity of the $\mathrm{TiO}_{2}$ layer was obtained by measuring sheet resistance using a four-point probe equipped with an HP 3468A electrometer. The conductivity value is inversely proportional to the sheet resistivity value. Figure 7 shows the electrical conductivity of the $\mathrm{TiO}_{2}$ layer at various concentrations. It was found that the electrical conductivity of the $\mathrm{TiO}_{2}$ layer increases as $\mathrm{TiO}_{2}$ concentration decreases, both opaque and transparent. The conductivity of the transparent layer is higher than the opaque layer. An opaque layer has a massive particle, which can be attributed to the high level of recombination and low electron density in the active layer [18].

Electrical performance of the fabricated perovskite solar cell with the configuration of $\mathrm{FTO} / \mathrm{CL}-\mathrm{TiO}_{2} / \mathrm{MS}$ $\mathrm{TiO}_{2} /$ Perovskite/ P3HT/Ag was presented in the currentvoltage curve, as seen in Figure 8 . In the transparent $\mathrm{TiO}_{2}$ layer (Figure $8(\mathrm{a})$ ), $\mathrm{V}_{\text {oc }}$ increases from the ratio of $1: 3$ to $1: 7$. Later, it decreases from a ratio of $1: 7$ to $1: 11$. While on the opaque $\mathrm{TiO}_{2}$ layer (Figure 8(b)), the change in $\mathrm{V}_{\text {oc }}$ value is not significant. The voltage of the transparent $\mathrm{TiO}_{2}$ layer increases from $0.07 \mathrm{~V}$ to $0.35 \mathrm{~V}$, and the voltage of the opaque $\mathrm{TiO}_{2}$ layer increases from $0.11 \mathrm{~V}$ to $0.18 \mathrm{~V}$. While in the resulting of $\mathrm{I}_{\mathrm{sc}}$ value, the transparent $\mathrm{TiO}_{2}$ layer is also higher than opaque $\mathrm{TiO}_{2}$ layer. Sample with $\mathrm{TiO}_{2}$ ratio of 1:7 has the high $\mathrm{V}_{\mathrm{oc}}$ and $\mathrm{I}_{\mathrm{sc}}$, both in the transparent and opaque $\mathrm{TiO}_{2}$ layer.

The performance parameters of the devices can be calculated from the I-V curve in Figure 7, and the results are presented in Table 2 . The performance parameter of the control (sample without $\mathrm{TiO}_{2}$ electron transfer layer) is also presented in the table. From Table 2 , we can see that sample "control" did not generate any current; meanwhile, the others did generate current with different values. This could be caused by the long travel distance electron must take before finally reach the electron transport layer to be transported to the FTO.

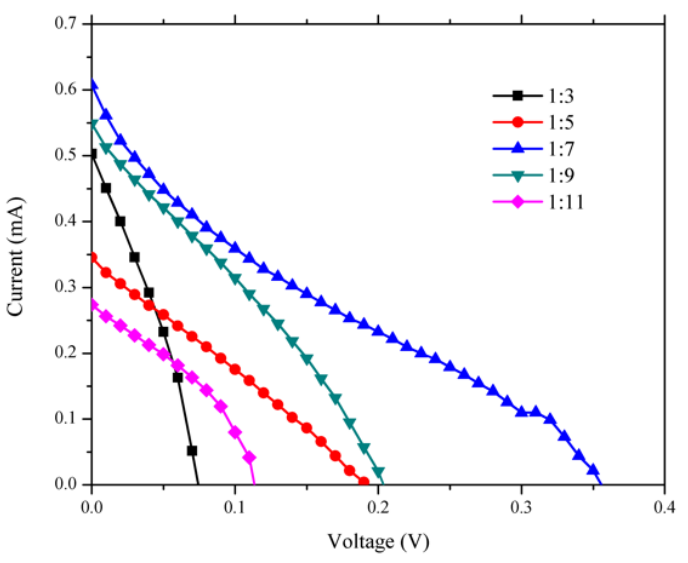

(a)

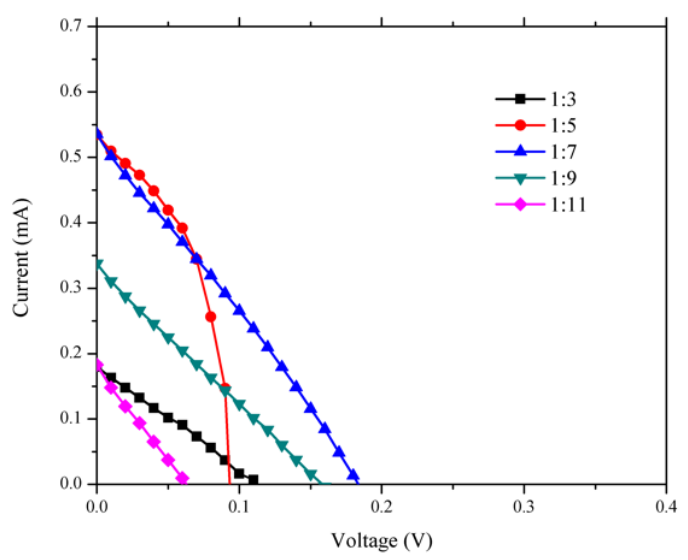

(b)

Figure 8. Current-voltage curves of perovskite solar cell with different $\mathrm{TiO}_{2}$ concentration with: (a) Transparent, (b) Opaque.

With a mesoporous structure that acts as a scaffold for the perovskite layer, electron travel distance is significantly reduced and, in turn, reducing the possibility of recombination [10].

As seen in the $\mathrm{I}-\mathrm{V}$ curve in Figure 7 , the $\mathrm{TiO}_{2}$ paste's ratio of $1: 7$ results in the highest $V_{\text {oc }}$ and $I_{s c}$, hence the resulting performance becomes the best. The power conversion efficiency (PCE) of the transparent $\mathrm{TiO}_{2}$ layer and opaque $\mathrm{TiO}_{2}$ layer is $0.37 \%$ and $0.21 \%$, respectively. Thus, the best performance is obtained by a transparent $\mathrm{TiO}_{2}$ layer.

TABLE 2

ELECTRICAL CHARACTERISTICS OF THE FABRICATED PEROVSKITE SOLAR CELL

\begin{tabular}{|l|c|c|c|c|}
\hline Sample Name & $\mathbf{V}_{\text {oc }}(\mathbf{V})$ & $\mathbf{J}_{\mathbf{s c}}\left(\mathbf{m A} / \mathbf{c m}^{2}\right)$ & $\mathbf{F F}$ & $\begin{array}{c}\text { PCE } \\
(\mathbf{\%})\end{array}$ \\
\hline Control & \multicolumn{4}{|c|}{ Not generating any current } \\
\hline $1: 3 \mathrm{~T}$ & 0.07 & 2.01 & 0.28 & 0.09 \\
\hline $1: 5 \mathrm{~T}$ & 0.19 & 1.38 & 0.15 & 0.14 \\
\hline $1: 7 \mathrm{~T}$ & 0.35 & 2.43 & 0.19 & 0.37 \\
\hline $1: 9 \mathrm{~T}$ & 0.20 & 2.19 & 0.27 & 0.26 \\
\hline $1: 11 \mathrm{~T}$ & 0.11 & 1.09 & 0.33 & 0.09 \\
\hline $1: 3 \mathrm{AO}$ & 0.11 & 0.71 & 0.25 & 0.04 \\
\hline $1: 5 \mathrm{AO}$ & 0.07 & 2.04 & 0.28 & 0.11 \\
\hline $1: 7 \mathrm{AO}$ & 0.18 & 2.14 & 0.21 & 0.21 \\
\hline $1: 9 \mathrm{AO}$ & 0.17 & 1.34 & 0.18 & 0.10 \\
\hline $1: 11 \mathrm{AO}$ & 0.06 & 0.73 & 0.27 & 0.02 \\
\hline
\end{tabular}


Overall, the resulting efficiency value is still very low compared to the perovskite solar cells in general, which is $>10 \%[10,13,19]$. The resulting low efficiency is due to low $V_{o c}$ and $I_{s c}$ values. The $V_{o c}$ value is determined by the difference between the LUMO electron transfer layer and the HOMO transfer hole layer on the perovskite solar cell work function diagram, as seen in Figure 1. The low $\mathrm{V}_{\mathrm{oc}}$ value $(<0.35$ $\mathrm{V}$ ) in this study can be caused by changes in the work function of one or both of these layers. The work function of a material can change when there are additives added to the material intentionally or not [20]. In this study, silver was estimated to act as an impurity entering $\mathrm{P}_{3} \mathrm{HT}$ semiconductor material, thereby increasing its conductive properties by changing its valence and conductive band values, which results in a reduced bandgap value. This short bandgap can cause a low $\mathrm{V}_{\mathrm{oc}}$ value obtained. Silver also makes the resulting low $I_{s c}$ values due to deeper penetration into the perovskite layer. In addition, optimization of the perovskite layer and hole P3HT HTM needs to be done further.

\section{CONCLUSION}

Perovskite solar cells have been fabricated with the configuration of $\mathrm{FTO} / \mathrm{CL}-\mathrm{TiO}_{2} / \mathrm{MS}-\mathrm{TiO}_{2} / \mathrm{Perovskite/}$ $\mathrm{P} 3 \mathrm{HT} / \mathrm{Ag}$. In order to optimize $\mathrm{TiO}_{2}$ mesoporous as an electron transport layer, the concentration of transparent and opaque $\mathrm{TiO}_{2}$ nanoparticles was varied. Results showed that transparent $\mathrm{TiO}_{2}$ had a higher conductivity and transmittance compared to opaque. The concentration of the $\mathrm{TiO}_{2}$ solution in a 1:17 ratio resulted in higher electrical performance in both transparent and opaque $\mathrm{TiO}_{2}$ layers. The best perovskite solar cell's performance with PCE of $0.37 \%$ was achieved from the sample using a transparent $\mathrm{TiO}_{2}$ layer with a concentration of 1:7 ratio.

\section{ACKNOWLEDGMENT}

The authors acknowledge the support from Material and Devices for Solar Cells research group at Research Center for Electronics and Telecommunication, Indonesian Institute of Sciences (P2ET, LIPI), and Surya University.

\section{REFERENCES}

[1] X. Yang, H. Wang, B. Cai, Z. Yu, and L. Sun, "Progress in hole transporting materials in perovskite solar cells," J. Energy Chem., vol. 27, pp. 650-672, May 2018.

[2] Y. Liu, Q. Chen, H. S. Duan, H. Zhou, Y. M. Yang, H. Chen, S. Luo, T. B. Song, L. Dou, Z. Hong, and Y. Yang, "A dopant-free organic hole transport material for efficient planar heterojunction perovskite solar cells," J. Mater. Chem. A, vol. 3, iss. 22 pp.11940-11947, Apr. 2015

[3] T. B. Song, Q. Chen, H. Zhou, C. Jiang, H. H. Wang, Y. (Michael) Yang, Y. Liu, J. You, and Y. Yang, "Perovskite solar cells: film formation and properties," J. Mater. Chem. A, 3, Iss. 17, pp. 9032-9050, Mar. 2015.

[4] E. S. Rosa, N. M. Nursam, Shobih, and R. Abdillah, "Improving the efficiency of perovskite solar cell through the addition of compact layer under $\mathrm{TiO}_{2}$ electron transfer material," Mater. Sci. Forum, vol. 929, pp. 218-224, 2018.

[5] Z. Wan, M. Xu, Z. Fu, D. Li, A. Mei, Y. Hu, Y. Rong, H. Han, "Screen printing process control for coating high throughput titanium dioxide layers toward printable mesoscopic perovskite solar cells," Front. Optoelectron., vol. 12, pp. 344-351, Apr. 2019

[6] J. You, Y. (Michael) Yang, Z. Hong, T. B. Song, L. Meng, Y. Liu, C. Jiang, H. Zhou, W. H. Chang, G. Li, and Y. Yang, "Moisture assisted perovskite film growth for high performance solar cells," Appl. Phys. Lett., 105. 183902. 10.1063/1.4901510. 2014 vol. 105, pp. 183902.1-183902.5, 2014.

[7] Z. Xiao, C. Bi, Y. Shao, Q. Dong, Q. Wang, Y. Yuan, C. Wang, Y. Gao, and J. Huang, "Efficient, high yield perovskite photovoltaic devices grown by interdiffusion of solutionprocessed precursor stacking layers," Energy Environ. Sci., vol. 7, iss. 8, pp. 2619-2623, May 2014.

[8] C. H. Chiang and C. G. Wu, "Bulk heterojunction perovskitePCBM solar cells with high fill factor," Nat. photonics, vol. 10, pp. 196-201, Feb. 2016.

[9] P. W. Liang, C. Y. Liao, C. C. Chueh, F. Zuo, S. T. Williams, X K. Xin, J. Lin, A. K.Y. Jen, "Additive enhanced crystallization of solution-processed perovskite for highly efficient planarheterojunction solar cells," Adv. Mater., vol. 26, iss. 22, pp. 3748-3754, Jun. 2014.

[10] J. You, L. Meng, T. B. Song, T. F. Guo, Y. (Michael) Yang, W. H. Chang, Z. Hong, H. Chen, H. Zhou, Q. Chen, Y. Liu, N. de Marco, and Y. Yang., "Improved air stability of perovskite solar cells via solution-processed metal oxide transport layers," Nat. Nanotech., vol. 11, pp. 75-81, Jan. 2016.

[11] T. S. Su, T. Y. Hsieh, C. Hong, and T. C. Wei, "Electrodeposited ultrathin $\mathrm{TiO}_{2}$ blocking layers for efficient perovskite solar cells," Sci. Rep., vol. 5, pp. 16098.1-16098.8, Nov. 2015.

[12] S. Ito, "Sensitization and functions of porous titanium dioxide electrodes in dye-sensitized solar cells and organolead halide perovskite solar cells," in Series on Chemistry, Energy, and Environment: Perovskite Solar Cells Principle, Materials and Devices, vol. 1, E. W. G. Diau and P. C. Y. Chen, Ed. Singapore: World Scientific, 2017, pp. 45-61

[13] G. Yang, H. Tao, P. Qin, W. Ke, and G. Fang, "Recent progress in electron transport layers for efficient perovskite solar cells," $J$. Mater. Chem. A, vol. 4, iss. 11, pp. 3970-3990, Jan. 2016.

[14] H. K. Park, D. K. Kim, and C. H. Kim, "Effect of dispersant on titania particle formation and morphology in thermal hydrolysis of $\mathrm{TiCl}_{4}$," J. Am. Ceram. Soc., vol. 80, iss. 3, pp. 743-749, Mar. 1997.

[15] S. Nakade, M. Matsuda, S. Kambe, Y. Saito, T. Kitamura, T. Sakata, Y. Wada, H. Mori, and S. Yanagida, "Dependence of $\mathrm{TiO}_{2}$ nanoparticle preparation methods and annealing temperature on the efficiency of dye-sensitized solar cells," $J$. Phys. Chem. B, vol. 106, iss. 39, pp. 10004-10010, Oct. 2002.

[16] S. Ito, T. N. Murakami, S. M. Zakeeruddin, T. Yazawa, M. Mizuno, S. Kayama, and M. Greatzel, "Effects of $\mathrm{TiO}_{2}$ particle size on the performance of dye-sensitized solar cells using ionic liquid electrolytes," Nano, vol. 9, no. 5, pp. 1440010.1$1440010.11,2014$

[17] Z. Wan, M. Xu, Z. Fu, D. Li, A. Mei, Y. Hu, Y. Rong, and H. Han, "Screen printing process control for coating high throughput titanium dioxide layers toward printable mesoscopic perovskite solar cells," Front. Optoelectron., vol. 12, pp. 344351, Apr. 2019

[18] H. Y. Yang, W. Y. Rho, S. K. Lee, S. H. Kim, and Y. B. Hahn, " $\mathrm{TiO}_{2}$ nanoparticles/nanotubes for efficient light harvesting in perovskite solar cells," Nanomater., vol. 9, iss. 3, pp. 326.1326.10, Mar. 2019.

[19] K. Sveinbjorrnsson, K. Aitola, J. Zhang, M. B. Johansson, X. Zhang, J. P. C. Baena, A. Hagfeldt, G. Boschloo, and E. M. J. Johansson, "Ambient air-processed mixed-ion perovskites for high efficiency solar cells," J. Mater. Chem. A, vol. 4, iss. 42, pp. 16536-16545, Sep. 2016.

[20] A. Hagfeldt, G. Boschloo, L. Sun, L. Kloo, and H. Petterson, "Dye-sensitized solar cells," Chem. Rev., vol. 110, no. 11, pp. 6595-6663, Sep. 2010. 